\title{
İnternet-medianın monitorinqi alətləri və informasiya təhlükəsizliyi məsələləri
}

\author{
Səadət Abdullayeva \\ İnformasiya Texnologiyaları İnstitutu, Bakı, Azərbaycan \\ sado.amea@gmail.com
}

\begin{abstract}
Xülasə- Məqalədə İnternet-media resurslarında informasiya təhlükəsizliyinin təmin olunmasında media monitorinqin rolu araşdırılır, mediada təhlükəsizliyə təhdid törədə biləcək risklərdən qorunmaq üçün təkliflər irəli sürülür. Həmçinin İnternet-media vo sosial mediada informasiya təhlükəsizliyinin təmin olunmasına imkan verən monitorinq və qiymətləndirmə xidmətləri göstərən şirkətlər haqqında məlumat verilir.
\end{abstract}

Açar sözlor- İternet-media; media monitorinq; medianın qiymotlondirilmosi; monitorinq alotlori; informasiya tohlükasizliyi

\section{GíRIŞ}

Müasir qloballaşma dövründə azad və müstəqil kütləvi informasiya vasitələri (KIV) cəmiyyətin həyatına təsir imkanlarına malikdir. Demokratik cəmiyyətlərdə KIV cəmiyyətin üzvlərinə əhəmiyyətli məsələlər üzrə müstəqil, obyektiv informasiya təqdim etdiyinə görə dördüncü hakimiyyət hesab edilir. KİV-in başlıca vəzifəsi cəmiyyəti onu maraqlandıran məsələlər barədə məlumatlandırmaq, zəruri informasiya ilə təmin etməkdir. Onun əsas funksiyası məhz ictimaiyyətin obyektiv informasiyaya olan tələbatını ödəməkdir. KIV bu vəzifəni informasiyanı qanunvericiliyə zidd olmayan üsullarla toplayıb hazırlamaq və yaymaqla həyata keçirməlidir.

KİV-in yeni növü olan İnternet-media ənənəvi media ilə müqayisədə, bir sira üstünlüklərə malikdir: İnternet-media əlyetərlidir; minimal xərc tələb edir; hamı üçün açıqdır istənilən şəxs qlobal kommunikasiya platformasına qoşula və informasiya mənbəyi kimi çıxış edə bilər; daha dinamik və çevikdir; əks əlaqə imkanları genişdir - auditoriyanın informasiya mənbəyi ilə qarşılıqlı təsir imkanı var; yüksək dərəcədə fərdiləşmə təklif edir; insanları vahid platformada birləşdirir və böyük həcmdə informasiya mübadiləsinə imkan verir [1].

İnternet-medianın media infrastrukturunda önəmli bir sahəyə çevrildiyi, əhalinin xeyli hissəsinin İnternet-media vasitəsilə informasiya əldə etdiyi bir dövrdə mili İnternet məkanının informasiya təhlükəsizliyinin təmin edilməsi zərurəti yaranmışdır. $\mathrm{Bu}$ baxımdan İnternet-medianın monitorinqi və informasiya təhlükəsizliyi ilə əlaqədar problemlərin araşdırılması vacib məsələlərdəndir.

\section{II. İNTERNET-MEDİADA İNFORMASIYYA TOHLÜKӘSIZLIYYININ TOMIN OLUNMASI}

Dövlət siyasətinin prioritet istiqamətlərindən biri də məhz, informasiyanın azad dövriyyəsinin təmin edilməsi, bu prosesin əsas aləti kimi medianın, o cümlədən İnternet-media resurslarının sərbəst fəaliyyətinə zəruri şəraitin yaradılmasıdır.

Dövlət qurumlarının veb-saytlarının informasiya siyasətinin əsas məqsədləri vətəndaşları öz fəaliyyətləri haqqında məlumatlandırmaq və onlarla əks əlaqəni təşkil etməkdir. Eyni zamanda, dövlət qurumları münaqişə, sosial gərginlik yarada bilən, yanlış ictimai rəy formalaşdıran, hakimiyyət orqanlarının nüfuzuna ziyan vura bilən informasiya təhdidlərinə operativ reaksiya verməyə borcludurlar.

Şəbəkə vasitəsilə cəmiyyətə informasiya təsiri mexanizmi hər yerdə eynidir: müəyyən sifarişçi vəzifəni təyin edir, onun icraçıları bu vəzifə üçün ictimai təşkilatlardan, jurnalistlərdən, siyasi fəallardan, qeyri-formal hərəkat üzvlərindən, bəzi hallarda isə, kriminal və ekstremist strukturlardan ibarət şəbəkə strukturunu qururlar. Onların bir qismini qrantlarla, bəzilərini siyasi piar vədləri ilə, digərlərini, sadəcə, pulla cəlb edirlər. Məhz onlar hərəkətverici qüvvədir, onlar insanları inandıra və öz arxaları ilə istənilən radikal aksiyalara apara bilərlər [1].

Digər tərəfdən, müasir dövrdə veb-texnologiyaların edövlətdə, mobil platformalarda, bank tranzaksiyalarında və $\mathrm{s}$. ilə yanaşı, sosial media və İnternet-media resurslarında geniş istifadə olunması ilə onlar bədniyyətlilərin hücum hədəfinə çevrilir, bu isə, veb-sistemlərdə informasiya təhlükəsizliyinin təmin olunması məsələsinin aktuallığını artırır. İnternet-media resurslarında olan boşluqların əvvəlcədən müəyyən olunması yarana biləcək bu və ya digər problemləri aradan qaldırmağa kömək edə bilər.

İnformasiya təhlükəsizliyinin əsasında informasiyanın mühafizəsi məsələləri dayanır. İnformasiya hüquqi, texniki, fiziki, kriptoqrafik üsullarla mühafizə olunur. İnformasiyanın mühafizəsi isə aşağıdakı hüquqi, təşkilati və texniki tədbirlər toplusunu özündə əks etdirir [2]:

- Informasiyanın tamlığının qorunması;

- Informasiyanın konfidensiallığının təmin edilməsi;

- İnformasiyanın əlyetərliliyinin təmin olunması; 


\section{“Informasiya tohlükosizliyinin aktual multidissiplinar elmi-praktiki problemlori” IV respublika konfransı, 14 dekabr 2018-ci il}

İnternet-mediada informasiyanın mühafizəsində bu üç şərt təmin edilməlidir. Bunun üçün mediada, eləcə də İnternetmediada informasiya təhlükəsizliyi məsələləri qanunlarla tənzimlənməlidir.

\section{III. İNTERNET-MEDİANIN MONITORINQI ALOTLӘRİ}

İnternet-medianın populyarlığının sürətlə artması, iqtisadi və ictimai-siyasi rolunun yüksəlməsi onun monitorinqi və analitikası üçün nəzərdə tutulmuş informasiya sistemlərinin yaradılmasını tələb edir [3].

Hazırda bazarda təklif olunan İnternet-media monitorinqi alətlərinin əksəriyyəti biznes məsələlərinin həllinə yönəlib. Onlar sosial mediada brendlərin, şirkətlərin, məhsulların və ya xidmətlərin adlarının neçə dəfə çəkildiyini müəyyən edir, istifadəçilərin onlara münasibətini (pozitiv, neqativ, neytral), rəylərin tonallığını aşkarlayır, rəy müəlliflərini cins, yaş, yaşayış yeri, maraqları və s. görə seqmentlərə bölür [4].

Öz fəaliyyətinin auditoriya tərəfindən daima yüksək qiymətləndirilməsinə çalışan İnternet-media resursları üçün aşağıda qeyd olunan tədbirlərin görülməsi zəruridir [5]:

- bütün monitorinq tədbirləri kompleks şəkildə həyata keçirilməli;

- monitorinqin digər metodlar ilə uyğunluğu nəzərə alınmalı;

- KIV-in azadlığının hüquqi aspektləri yenidən işlənilməli;

- monitorinq zamanı KİV-in auditoriyasının kritik vəziyyət nöqtələri müəyyən olunmalıdır.

Sosial mediada monitoring zamanı ilkin olaraq informasiyalar izlənir, mətnlər analiz olunur, spam şərhlər müəyyən olunur. Növbəti addımlarda mətnlərin müxtəlif xüsusiyyətlərinə görə daha ətraflı təhlil aparılır. Daha sonra isə vizualizasiya və yarana biləcək təhdidlərə qarşı tədbirlər görülür [3].

Qeyd edək ki, populyar sosial şəbəkə servislərində bir sıra monitorinq alətləri mövcuddur. Məsələn, Facebook Insights, Google Analytics, Twitter Analytics, LinkedIn Analytics, Pinterest Analytics və s.. Hazırda ingilisdilli SumAll, Sysomos, UberVU, SproutSocial portalları, rusdilli InfoWatch Kribrum, YouScan, Brand Analytics, Babkee, BrandSpotter, Buzz Look, IQBuzz, SemanticForce, Wobot, və s. sosial media monitorinqi xidmətləri təklif edilir [1].

“InfoWatch Kribrum” İnternet-medianın, eləcə də sosial medianın monitorinqi vo analizinin avtomatlaşdırılmış sistemidir. Sistem gün ərzində real vaxt rejimində mətnlərin tonallığını müəyyən etməklə, həmçinin informasiya hücumlarını və spamları aşkar etməklə müxtəlif sosial şəbəkələrdə, bloqlarda və $20 \mathrm{~min}$ İnternet-media resursunda 250 milyon istifadəçi hesabında 60 milyondan çox mesajın analizini təqdim edir [6]. "InfoWatch Kribrum" vasitəsilə əldə olunmuş məlumatların əsasını İnternetdə sifarişçini maraqlandıran mövzular üzrə informasiya sahəsi üzrə vəziyyətə dair aylıq, həftəlik və gündəlik analitik hesabatlar təşkil edir. Sistemin funksional imkanlarına məlumatların toplanması, analizi, auditoriya ilə interaktiv əlaqə, sistem üzərində birgə iş, hesabatların işlənməsi və inteqrasiya daxildir.

$\mathrm{Bu}$ sistem, həmçinin İnternet-media resurslarında informasiya təhlükəsizliyi üçün həllər təklif edir:

- sosial mediada informasiya hücumlarının aşkar edilməsi;

- informasiya hücumunun mənbəyinin və onun yayılması yollarının üzə çıxardılması;

- veb-sayta şirkətin əməkdaşları tərəfindən təhdidlərin aşkara çıxarılması;

- korporativ informasiyanın qanunsuz yayılmasının aşkar edilməsi;

- onlayn mühitdə istifadəçilərin məxfiliyinin qorunmasına xidmət edən TOR proqram təminatı üzrə axtarış.

Qeyd olunan sistemlərin hər biri onlayn media resurslarında informasiya təhlükəsizliyinin təmin olunmasında böyük imkanlara malikdir.

Azərbaycanda isə, medianın monitorinqi və qiymətləndirilməsini Media Təqib Mərkəzi, "Kalibri” media monitorinq şirkəti, Azərbaycan Media Monitorinqi İnstitutu, "MC\&S" media monitorinq qrupu və digər şirkətlər həyata keçirir [4]. Bu şirkətlər medianın və sosial şəbəkələrin analizini və marketinq strategiya və taktikasının qurulması istiqamətində geniş spektrli, operativ və peşəkar xidmətlərin göstərilməsini təklif edir. Onların xidmət sahələrinə ölkə mediası, xarici ölkələrin mediası, mətbuat, televiziya yayımları, radio, sosial media, İnternet-media, xəbər agentlikləri, televiziya reklamlarının monitorinqi və s. daxildir.

Ölkəmizdə monitorinqi həyata keçirən şirkətlərin say1 kifayət qədər olsa da, medianın monitorinqinə kompleks yanaşmalar tələb olunur. Bunun səbəbi, monitorinqin aparılmasında pərakəndəliyin mövcud olmas1, bu sahənin qanunlarla tənzimlənməməsi nəticəsində etimad mühitinin zəif olması və informasiya təhlükəsizliyinə təhdidlərin olması, zəruri mədəniyyətin formalaşmaması, o cümlədən İnternet resursları üçün milli statistika mexanizmlərinin mövcud olmamasidir.

\section{MEDİADA İNFORMASIYYA TӘHLÜKӘSIZLIYINO KOMPLEKS YANAŞMA}

Məlumdur ki, informasiya texnologiyaları və xidmətlərdən asılılığın artması ilə dezinformasiya və təbliğat üçün potensial risklər yüksəlir. İnformasiyanın dayanıqlılı̆̆ vəziyyətlərdə (informasiyanın təhlükəsizliyinə təhdidlər olduqda) tədbirlərin görülməsi sistemi vasitəsilə təmin olunmalıdır (Şəkil 1.) [7]. Media müasir cəmiyyətin ayrılmaz 


\section{“Informasiya tohlükosizliyinin aktual multidissiplinar elmi-praktiki problemlori” IV respublika konfransı, 14 dekabr 2018-ci il}

tərkib hissəsi olduğundan informasiya təhlükəsizliyinə kompleks yanaşmanın işlənilməsi zəruridir.

Şəkil 1. Mediada informasiya təhlükəsizliyinə kompleks yanaşma [7]

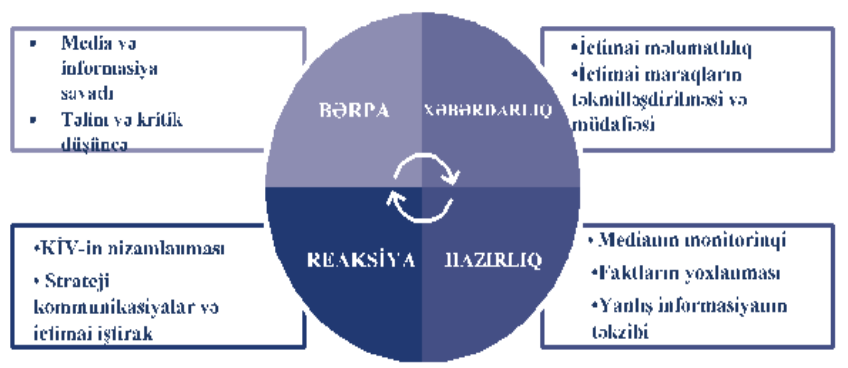

Cəmiyyət informasiyanın sabitliyini yüksəltməli və fövqəladə vəziyyətləri idarəetmə metodları vasitəsilə informasiya təhdidləri ilə mübarizə aparmalıdır. Fövqəladə vəziyyətləri idarəetmə prosesi dörd mərhələdən ibarətdir: xəbərdarlıq, hazırlıq, reaksiya və bərpa.

Xəbərdarlıq potensial fövqəladə vəziyyətlərin neqativ nəticələrini minimallaşdıra bilər. Qabaqlayıcı tədbirlər ictimaiyyətə dezinformasiyanın təhlükələri barədə məlumat verilməsi və ictimai müzakirələrə onun neqativ təsiri haqqında məlumatlandırılmanı nəzərdə tutur.

Hazırlıq erkən xəbərdarlıq sistemi rolunu oynayır və medianın monitorinq mexanizmlərini və məzmun barədə məlumatlandırılmanı nəzərdə tutur. Hazırlıq mərhələsində ənənəvi KIV və sosial mediada təhrif olunmuş informasiyanın və onun mövcudluğu haqqında xəbərdarlığın müəyyən olunması üçün insan resursları və texnoloji resurslar istifadə olunur.

Reaksiya mexanizmləri dezinformasiya və təbliğat xarakterli informasiya ilə mübarizə üçün istifadə edilən əkstədbirləri təşkil edir. Onlar özündə qanunvericilik bazasının işlənilməsi və KİV-in nizamlanması orqanının effektivliyinin artırılmasını, həmçinin strateji kommunikasiyalar üçün ictimaiyyətin iştirakının gücləndirilməsi və institusional potensialın artırılmasını ehtiva edir.

Nəhayət, bərpa mərhələsi kütləvi informasiya vasitələrinin ictimaiyyətə vicdanla xidmət etdiyi, cəmiyyətin isə, manipulyasiyalara ayıq olduğu bir mühitin yaradılması üçün nəzərdə tutulmuşdur. Bunun üçün maarifləndirici proqramlar üçün media savadlılığını və kritik düşünmə qabiliyyətini yüksəldəcək uzunmüddətli investisiyalar tələb olunur [7].

İnternet-media resurslarının monitorinqinin aparılması media qurumlarına olan kiberhücümlar zamanı aşağıdakıların həllinə imkan verir [8]:

- kiberhücumu həyata keçirmək imkanının ləğv olunması və bununla zərərin qarşısının alınması;

- zərərin minimuma endirilməsi istiqamətində tədbirlərin görülməsi;
- $\quad$ təhlükəyə meyilli resursların sayının azaldılması;

- $\quad$ problemin aradan qaldırılma vaxtının azaldılmasi;

- $\quad$ erkən xəbərdarlığın təmin olunması;

- hücumdan sonra cinayətkarın aşkar edilməsi.

İnternet-mediada etibarlı informasiya təhlükəsizliyi sistemi qurmaq üçün, ilk növbədə, hüquqi baza formalaşdırılmalıdır. Azərbaycanda bu sahədə müəyyən hüquqi baza mövcuddur. Lakin sürətlə inkişaf edən və bütün sahələrə getdikcə daha dərindən nüfuz edən informasiya texnologiyalarının formalaşdırdığı informasiya mühitinin lazımi səviyyədə hüquqi tənzimlənməsi üçün qanunvericilik sistemi də baş verən dəyişikliklərə, yeniliklərə çevik reaksiya verməli, daim yenilənməli, təkmilləşməlidir.

\section{NӘTİCӘ}

İnternet-mediada informasiya təhlükəsizliyinin təmin olunması üçün aşağıdakı tədbirlərin görülməsi təklif edilir:

- Mediada informasiya təhlükəsizliyi sahəsində qanunvericilik bazasının formalaşdırılması;

- Internet-media resurslarında yayılan təbliğat xarakterli informasiya, dezinformasiya, eləcə də milli-mənəvi dəyərlərə zidd olan informasiyalar haqqinda erkən xəbərdarlıq sisteminin hazırlanması;

- Milli Televiziya və Radio Şurasının İnternet-televiziya və radioların monitorinqinə dair səlahiyyətlərinin genişləndirilməsi;

- İnformasiya təhlükəsizliyi və risklərinin yeni problemlərinin həlli üçün KIV haqqında qanunvericiliyə əlavə və dəyişikliklərin edilməsi;

- İnternet-medianın inkişaf strategiyasının hazırlanması, jurnalistlərin fəaliyyətinin stimullaşdırılması üçün əlverişli şəraitin yaradılması;

- Medianın və informasiya savadının dövlət qurumları tərəfindən dəstəklənməsinin təmin edilməsi;

Qeyd olunan təkliflərin ölkə səviyyəsində reallaşdırılması üçün bir sıra ölkələrdə bu sahədə tətbiq olunan təcrübədən istifadə edilməsi müsbət nəticələr verə bilər.

Beləliklə, İnternet-mediada insan hüquqları və ifadə azadlığını pozmadan kontentin monitorinqi və qiymətləndirilməsi cəmiyyətin nəbzini tutmağa, əhvalruhiyyəsini müəyyən etməyə, gözləntilərini aşkarlamağa imkan verir. İnternet-media, eləcə də sosial medianın monitorinqi vasitəsilə meydana çıxan təhdidləri vaxtında aşkarlamaq və əks-tədbirlər həyata keçirmək mümkündür.

\section{ӘDӘBIYYYAT}

[1] İmamverdiyev Y.N., Sosial media və təhlükəsizlik problemləri, İnformasiya cəmiyyəti problemləri, 2016, №2, 19-25

[2] Mahmudov R., İnformasiya təhlükəsizliyinin normativ-hüquqi bazası //Azərbaycan xalqının ümummilli lideri Heydər Oliyevin 90 illik 
yubileyinə həsr olunmuş "İnformasiya təhlükəsizliyi problemləri üzrə I respublika elmi-praktiki konfransı”, 17-18 may, 2013

[3] M.D. Sykora et al. National security and social media monitoring: A presentation of the emotive and related systems / European Intelligence and Security Informatics Conference, 2013, pp. 172-175.

[4] R.M. Oliquliyev, S.R. Ağayeva, "İnternet-media resurslarının monitorinqi: müasir vəziyyətləri, problemləri və inkişaf perspektivləri. İnformasiya cəmiyyəti problemləri, 2016, №1, s. 63 - 70 .

[5] Шарков Ф.И., Баранова В.И., “Аудитория и мониторинг СМИ.” 2005, 110 стр.

[6] InfoWatch Kribrum, https://infowatch.com/products/kribrum

[7] Д.Марин, Повышение устойчивости информации в медиа-секторе, "Media Forward" Серия политических обзоров, № 4, 2018, 8 c.

[8] E. E. Schultz, "Continuous monitoring: What it is, why it is needed, and how to use it." SANS Institute InfoSec Reading Room, 2011, 16 p.

\section{ONLINE MEDIA MONITORING TOOLS AND}

INFORMATION SECURITY ISSUES

\author{
Saadat Abdullayeva
}

Institute of Information Technology of ANAS, Baku,

Azerbaijan

sado.amea@gmail.com

Abstract - The role of media monitoring in ensuring information security in online media resources is being investigated in the article and is offered suggestions for protection against potential threats to security in media. It also provides information about monitoring and evaluation services that provide information security in online media, as well as in social media.

Keywords - online media; media monitoring; media evaluation; monitoring tools; information security 